Review Article

DOI: $10.36959 / 736 / 637$

\title{
Synthetic Endocrine Disrupting Chemicals are not a Significant Cause of Obesity
}

\author{
Carr J Smith ${ }^{1 *}$ (D), Thomas A Perfetti2 ${ }^{2}$ A Wallace Hayes ${ }^{3}$ and Sir Colin Berry ${ }^{4}$ \\ ${ }^{1}$ Albemarle Corporation, Alabama, USA \\ ${ }^{2}$ Perfetti \& Perfetti, LLC, Winston-Salem, NC, USA \\ ${ }^{3}$ University of South Florida College of Public Health and Institute for Integrative Toxicology, Michigan State University, \\ USA
}

${ }^{4}$ Queen Mary University of London, UK

\begin{abstract}
Background: Obesity is a worldwide epidemic with approximately two billion adults classifiable as overweight and over 600 million as obese. In the US, approximately two-thirds of adults over age 20 are overweight with about $35 \%$ currently obese with the obesity percentage steadily rising.

Aim: Obesity is a complex disease wherein an excessive amount of body fat accumulates from ingesting more calories than are burned. Obesity usually results from a combination of factors including genetics, ready availability of inexpensive high caloric foods, low exercise levels or sedentary lifestyles, and poor dietary choices.

Methods: This paper provides an overview of the available information on synthetic endocrine disrupter chemicals and reasons why these chemicals are not a significant cause of obesity.

Results: Prenatal effects of exposure to synthetic endocrine disrupting chemicals (EDCS) have been proposed as a causative factor in the obesity epidemic. Population effects from prenatal EDCs would be expected to be very minor as exposures to EDCs are very low; and humans are routinely exposed to a huge number and high concentration of naturally occurring chemicals with potential endocrine effects. Further reducing exposures to the trace amounts of EDCs in the environment would not be expected to measurably ameliorate the obesity epidemic which is mainly being driven by excessive caloric intake of high carbohydrate and high sugar content foods.
\end{abstract}

Conclusions: While exposure to synthetic EDCs is not a major factor in developing obesity, the converse is true; adipose tissue is an important source of estrogens, testosterone, thyroid stimulating hormone, leptin and approximately 500 biologically active compounds termed adipokines. The hormonal and pro-inflammatory effects of adipose tissue underlie the association between obesity and increased risk of a number of chronic diseases.

\section{Keywords}

Obesity, Endocrine disrupting chemicals, EDCs, Adipokines, Naturally occurring EDCs

\section{Introduction}

Obesity is a worldwide epidemic with approximately two billion adults classifiable as overweight and over 600 million as obese [1]. In the US, approximately two-thirds of adults over age 20 are overweight with about $35 \%$ currently obese with the obesity percentage steadily rising [2]. Obesity is a complex disease wherein an excessive amount of body fat accumulates from ingesting more calories than are burned. Obesity usually results from a combination of factors including genetics, ready availability of inexpensive high caloric foods, low exercise levels or sedentary lifestyles, and poor dietary choices. Prenatal effects of exposure to synthetic en- docrine disrupting chemicals (EDCs) have been proposed as a causative factor in the obesity epidemic [3].

*Corresponding author: Carr J Smith, Ph.D, DABT, Albemarle Corporation, 6400 Brindlewood Court Mobile, Alabama 36608, USA

Accepted: November 10, 2020

Published online: November 12, 2020

Citation: Smith CJ, Perfetti TA, Hayes AW, et al. (2020) Synthetic Endocrine Disrupting Chemicals are not a Significant Cause of Obesity. Ann Toxicol 2(1):36-44 
We recently published two reviews on obesity $[4,5]$. In these reviews, the putative relationship between EDCs and obesity was noted: "The adverse health effects of obesity are likely to be extensive and include many factors apart from the widely understood type 2 diabetes risk."

"A significant body of literature reports that exposure to endocrine disrupting chemicals can adversely affect the endocrine glands, with an increased tendency toward developing obesity among the notable effects [6]. Any study on the potential adverse effects of exposures to relatively low concentrations of chemicals that might alter the endocrine system must take into account the very high percentages of societal obesity and the clear biological activity of the many molecules released by adipose tissue."

\section{Exposure to synthetic endocrine disrupting chemicals (EDCs) is very low}

The World Health Organization (WHO) defines an endocrine disrupting chemical (EDC) as an "exogenous substance or mixture that alters function(s) of the endocrine system and consequently causes adverse health effects in an intact organism, or its progeny, or (sub) populations" [3]. Under the auspices of the United Nations (UN) Environment Programme, the International Panel on Chemical Pollution (IPCP) has published a list of 45 chemicals from 11 structural groups classified as EDCs or potential EDCs [7]. This list has been adopted by the European Commission. Forty-eight additional chemicals are under consideration by the European Chemicals Agency (ECHA) for classification as EDCs [8].

The United States National Institute of Environmental Health Sciences (NIEHS) describes three common mechanisms by which EDCs can exert their effects [9]. First, EDCs can possess estrogenic or androgenic activity, or mimic or partially mimic the activity of thyroid hormones. Second, EDCs can function as anti-estrogens or anti-androgens via intracellular receptor binding. Third, EDCs can adversely impact either the synthesis or regulation of hormone receptors thereby altering receptor function, e.g. liver metabolism of receptors. Exposure to EDCs is of particular concern in situations characterized by rapid cellular development including pregnancy and infancy [9].

In the previously noted recent review, we [4] discussed the mechanisms of obesity, insulin resistance, and the metabolic syndrome; and also reviewed the mechanisms of obesity-related alterations in bone density, composition, and resilience to fracture; and presented the diverse mechanisms associated with cancer and obesity.

Numerous regulatory agencies in the United States and in the European Union have programs directed at understanding EDCs (European Food Safety Authority (EFSA); US Environmental Protection Agency (US EPA); US EPA, [10-13]. Human exposure to a number of the 45 EDCs adopted by the European Commission has been measured (Table 1). Expo-

Table 1: Reported levels of the 45 Endocrine Disrupting Chemicals (EDCs) in human body fluids.

\begin{tabular}{|c|c|c|c|c|c|}
\hline $\begin{array}{l}\text { Endocrine Disrupting Chemicals } \\
\text { (EDC) Adopted by the European } \\
\text { Commission (EC) }\end{array}$ & CAS RN & Chemical Class & $\begin{array}{l}\text { Regulatory } \\
\text { Status }\end{array}$ & $\begin{array}{l}\text { Reported levels of EDCs in } \\
\text { Human Body Fluids (blood, } \\
\text { plasma, umbilical cord fluid, } \\
\text { etc.) or Urine* }\end{array}$ & References \\
\hline $\begin{array}{l}\text { Benzophenone-2; } 2,2^{\prime}, 4,4^{\prime}- \\
\text { tetrahydroxybenzophenone }\end{array}$ & $131-55-5$ & Benzophenone & $\begin{array}{l}\text { Component } \\
\text { Under Study }\end{array}$ & $0.05-0.07 \mathrm{ng} / \mathrm{ml}$ & [17] \\
\hline Benzophenone-3; Oxybenzone & $131-57-7$ & Benzophenone & $\begin{array}{l}\text { Component } \\
\text { Under Study }\end{array}$ & $60-140 \mathrm{ng} / \mathrm{ml}$ & {$[20]$} \\
\hline Benzyl butyl phthalate; BBP & $85-68-7$ & Phthalate & $\begin{array}{l}\text { Sunset date, } \\
02 / 21 / 2015\end{array}$ & $\mathrm{BDL}(0.2 \mathrm{ng} / \mathrm{mL})$ & {$[14]$} \\
\hline $\begin{array}{l}\text { 3-Benzylidene camphor (3-BC); } \\
\text { 1,7,7- trimethyl-3- (phenylmethylene) } \\
\text { bicyclo[2.2.1] heptan-2- one }\end{array}$ & $15087-24-8$ & Camphor & $\begin{array}{l}\text { Component } \\
\text { Under Study }\end{array}$ & BDL & [15] \\
\hline Bis(2-ethylhexyl) phthalate (DEHP) & $117-81-7$ & Phthalate & $\begin{array}{l}\text { Sunset date, } \\
02 / 21 / 2015\end{array}$ & $103.55 \pm 92.98 \mathrm{ng} / \mathrm{ml}$ & {$[25]$} \\
\hline Bisphenol F & $620-92-8$ & Phenol & $\begin{array}{l}\text { Component } \\
\text { Under Study }\end{array}$ & $212 \mathrm{ng} / \mathrm{ml}$ & [23] \\
\hline Bisphenol S & 80-09-1 & Phenol & $\begin{array}{l}\text { Component } \\
\text { Under Study }\end{array}$ & $12.3 \mathrm{ng} / \mathrm{ml}$ & {$[23]$} \\
\hline Butylated hydroxytoluene & $128-37-0$ & Phenol & $\begin{array}{l}\text { Component } \\
\text { Under Study }\end{array}$ & $4.4-273.9 \mathrm{ng} / \mathrm{g}$ & [28] \\
\hline Butylparaben; butyl 4-hydroxybenzoate & $94-26-8$ & Phenol & $\begin{array}{l}\text { Component } \\
\text { Under Study }\end{array}$ & $0.03-0.42 \mathrm{ng} / \mathrm{ml}$ & [18] \\
\hline Carbon disulphide & $75-15-0$ & Bisulphide & $\begin{array}{l}\text { Component } \\
\text { Under Study }\end{array}$ & BDL Very short half-life & None \\
\hline Dibutyl phthalate (DBP) & $84-74-2$ & Phthalate & $\begin{array}{l}\text { Sunset date, } \\
02 / 21 / 2015\end{array}$ & $0.18-13.47 \mu \mathrm{g} / \mathrm{mL}$ & [27] \\
\hline
\end{tabular}


Citation: Smith CJ, Perfetti TA, Hayes AW, et al. (2020) Synthetic Endocrine Disrupting Chemicals are not a Significant Cause of Obesity. Ann Toxicol 2(1):36-44

\begin{tabular}{|c|c|c|c|c|c|}
\hline Dicyclohexyl phthalate (DCHP) & $84-61-7$ & Phthalate & $\begin{array}{l}\text { Component } \\
\text { Under Study }\end{array}$ & $\mathrm{BDL}(0.2 \mathrm{ng} / \mathrm{mL})$ & {$[14]$} \\
\hline Diethyl phthalate (DEP) & $84-66-2$ & Phthalate & $\begin{array}{l}\text { Component } \\
\text { Under Study }\end{array}$ & $0.64-3.11 \mu \mathrm{g} / \mathrm{mL}$ & [27] \\
\hline Dihexyl phthalate (DHP) & $84-75-3$ & Phthalate & $\begin{array}{l}\text { Component } \\
\text { Under Study }\end{array}$ & $\mathrm{BDL}(0.2 \mathrm{ng} / \mathrm{mL})$ & {$[14]$} \\
\hline 4,4'-Dihydroxybenzophenone & 611-99-4 & Benzophenone & $\begin{array}{l}\text { Component } \\
\text { Under Study }\end{array}$ & BDL Very short half-life & None \\
\hline Diisobutyl phthalate (DiBP) & $84-69-5$ & Phthalate & $\begin{array}{l}\text { Sunset date, } \\
02 / 21 / 2015\end{array}$ & $\mathrm{BDL}(0.2 \mathrm{ng} / \mathrm{mL})$ & {$[14]$} \\
\hline Diisodecyl phthalate (DiDP) & $26761-40-0$ & Phthalate & $\begin{array}{l}\text { Component } \\
\text { Under Study }\end{array}$ & $\mathrm{BDL}(0.2 \mathrm{ng} / \mathrm{mL})$ & {$[14]$} \\
\hline p-(1,1-Dimethylpropyl) phenol & $80-46-6$ & Phenol & $\begin{array}{l}\text { Component } \\
\text { Under Study }\end{array}$ & BDL Very short half-life & None \\
\hline Dioctyl phthalate (DOP) & $117-81-7$ & Phthalate & $\begin{array}{l}\text { Sunset date, } \\
02 / 21 / 2015\end{array}$ & $\mathrm{BDL}(0.2 \mathrm{ng} / \mathrm{mL})$ & {$[14]$} \\
\hline $\begin{array}{l}\text { Diundecyl phthalate (DuDP), branched and } \\
\text { linear }\end{array}$ & $85507-79-5$ & Phthalate & $\begin{array}{l}\text { Component } \\
\text { Under Study }\end{array}$ & $\mathrm{BDL}(0.2 \mathrm{ng} / \mathrm{mL})$ & {$[14]$} \\
\hline 2-Ethylhexyl 4-methoxycinnamate & $5466-77-3$ & Acrylate & $\begin{array}{l}\text { Component } \\
\text { Under Study }\end{array}$ & $5-8 \mathrm{ng} / \mathrm{ml}$ & {$[20]$} \\
\hline Ethylparaben & $120-47-8$ & Phenol & $\begin{array}{l}\text { Component } \\
\text { Under Study }\end{array}$ & $0.02-31.7 \mathrm{ng} / \mathrm{mL}$ & {$[80]$} \\
\hline 4-Heptylphenol, branched and linear & $\begin{array}{l}\text { 1987-50-4, } \\
72624-02-3\end{array}$ & Phenol & $\begin{array}{l}\text { Component } \\
\text { Under Study }\end{array}$ & BDL Very short half-life & None \\
\hline Metam-sodium & $137-42-8$ & Dithiocarbamate & $\begin{array}{l}\text { Component } \\
\text { Under Study }\end{array}$ & BDL Very short half-life & None \\
\hline $\begin{array}{l}\text { 3-(4-Methylbenzylidene) camphor; } 1,7,7- \\
\text { trimethyl-3-[(4-methylphenyl) methylene] } \\
\text { bicyclo[2.2.1] heptan-2-one }\end{array}$ & $36861-47-9$ & Camphor & $\begin{array}{l}\text { Component } \\
\text { Under Study }\end{array}$ & $16-18 \mathrm{ng} / \mathrm{ml}$ & {$[15]$} \\
\hline Methylparaben (MPB) & $99-76-3$ & Phenol & $\begin{array}{l}\text { Component } \\
\text { Under Study }\end{array}$ & $43.9 \mathrm{ng} / \mathrm{mL}$ & {$[24]$} \\
\hline 4-Nitrophenol & $100-02-7$ & Phenol & $\begin{array}{l}\text { Component } \\
\text { Under Study }\end{array}$ & BDL Very short half-life & None \\
\hline 4-Nonylphenol, branched and linear & - & Phenol & $\begin{array}{l}\text { Component } \\
\text { Under Study }\end{array}$ & $32 \mathrm{ng} / \mathrm{mL}$ & [19] \\
\hline $\begin{array}{l}\text { 4-Nonylphenol, branched and linear, } \\
\text { ethoxylated }\end{array}$ & - & Phenol & $\begin{array}{l}\text { Sunset date, } \\
01 / 04 / 2021\end{array}$ & $0.07-0.16 \mathrm{ng} / \mathrm{ml}$ & [19] \\
\hline Pentachlorophenol (PCP) & $87-86-5$ & Phenol & $\begin{array}{l}\text { Component } \\
\text { Under Study }\end{array}$ & $109.6 \mathrm{ng} / \mathrm{ml}$ & {$[26]$} \\
\hline Propylparaben; propyl 4-hydroxybenzoate & $94-13-3$ & Phenol & $\begin{array}{l}\text { Component } \\
\text { Under Study }\end{array}$ & $2.9-60.4 \mathrm{ng} / \mathrm{ml}$ & [81] \\
\hline $\begin{array}{l}\text { Quadrosilan; 2,6-cis- } \\
\text { Diphenylhexamethylcyclotetrasiloxane }\end{array}$ & $33204-76-1$ & Siloxane & $\begin{array}{l}\text { Component } \\
\text { Under Study }\end{array}$ & - & None \\
\hline $\begin{array}{l}\text { 2,4-Dihydroxybenzophenone } \\
\text { (Resbenzophenone) }\end{array}$ & $131-56-6$ & Benzophenone & $\begin{array}{l}\text { Component } \\
\text { Under Study }\end{array}$ & $2.2-6.3 \mathrm{ng} / \mathrm{ml}$ & [17] \\
\hline Resorcinol & $108-46-3$ & Phenol & $\begin{array}{l}\text { Component } \\
\text { Under Study }\end{array}$ & BDL & [16] \\
\hline Tebuconazole & 107534-96-3 & Triazole & $\begin{array}{l}\text { Component } \\
\text { Under Study }\end{array}$ & - & None \\
\hline $\begin{array}{l}\text { Tert-butylhydroxyanisole (BHA); tertbutyl- } \\
\text { 4-methoxyphenol }\end{array}$ & 25013-16-5 & Phenol & $\begin{array}{l}\text { Component } \\
\text { Under Study }\end{array}$ & Very short half-life & {$[82]$} \\
\hline $\begin{array}{l}\text { Tert-butyl methyl ether; MTBE; 2- } \\
\text { methoxy-2-methylpropane }\end{array}$ & $1634-04-4$ & Ether & $\begin{array}{l}\text { Component } \\
\text { Under Study }\end{array}$ & $5-20 \mathrm{ng} / \mathrm{ml}$ & {$[83]$} \\
\hline
\end{tabular}


Citation: Smith CJ, Perfetti TA, Hayes AW, et al. (2020) Synthetic Endocrine Disrupting Chemicals are not a Significant Cause of Obesity. Ann Toxicol 2(1):36-44

\begin{tabular}{|c|c|c|c|c|c|}
\hline 4-(1,1,3,3-Tetramethylbutyl)phenol & $140-66-9$ & Phenol & $\begin{array}{l}\text { Sunset date, } \\
01 / 04 / 2021\end{array}$ & $0.2-20.6 \mathrm{ng} / \mathrm{ml}$ & [19] \\
\hline $\begin{array}{l}\text { 4-(1,1,3,3-Tetramethylbutyl)phenol, } \\
\text { ethoxylated }\end{array}$ & - & Phenol & $\begin{array}{l}\text { Component } \\
\text { Under Study }\end{array}$ & BDL Very short half-life & None \\
\hline Thiram & $137-26-8$ & Dithiocarbamate & $\begin{array}{l}\text { Component } \\
\text { Under Study }\end{array}$ & BDL Very short half-life & None \\
\hline 2,4,6-Tribromophenol & |118-79-6 & Phenol & $\begin{array}{l}\text { Component } \\
\text { Under Study }\end{array}$ & BDL Very short half-life & None \\
\hline Triclosan & 13380-34-5 & Phenol & $\begin{array}{l}\text { Component } \\
\text { Under Study }\end{array}$ & $5.9 \mathrm{ng} / \mathrm{ml}$ & {$[21]$} \\
\hline Triphenyl phosphate & $115-86-6$ & Phenol & $\begin{array}{l}\text { Component } \\
\text { Under Study }\end{array}$ & $2.9 \mathrm{ng} / \mathrm{ml}$ & {$[22]$} \\
\hline Zineb & $12122-67-7$ & Dithiocarbamate & $\begin{array}{l}\text { Component } \\
\text { Under Study }\end{array}$ & BDL Very short half-life & None \\
\hline Ziram & 137-30-4 & Dithiocarbamate & $\begin{array}{l}\text { Component } \\
\text { Under Study }\end{array}$ & BDL Very short half-life & None \\
\hline
\end{tabular}

*BDL Very short half-life means the ED is metabolized very rapidly and the parent compound was eliminated.

sure levels to the 45 EDCs are very low. Eleven of the 45 EDCs are metabolized very rapidly with the resultant half-life being so short that exposure cannot be measured as the parent compound is eliminated prior to detection. The rapidly metabolized EDCs include the following chemicals: Carbon disulphide (CASRN 75-15-0); 4,4'-dihydroxybenzophenone (CARN 611-99-4); p-(1,1-dimethylpropyl) phenol (CASRN 80-46-6); 4-heptylphenol, branched and linear (CASRN 1987-50-4 and CARN 72624-02-3); metam-sodium (CASRN137-42-8); 4-nitrophenol (CASRN 100-02-7); 4-(1,1,3,3-tetramethylbutyl) phenol, ethoxylated; Thiram (CASRN137-26-8); 2,4,6-tribromophenol(CASRN118-79-6); Zineb (CASRN 12122-67-7); and Ziram (CASRN|137-30-4).

For example, oral absorption of metam-sodium is rapid and almost complete (85\%) based on urinary and expired air excretion (50 and 35\%, respectively). The metabolism of metam is extensive and rapid, suggesting a decomposition of metam into MITC (methylisothiocyanate), $\mathrm{CO}_{2}$, and COS. MITC is further conjugated to glutathione and excreted in urine while $\mathrm{CO}_{2}, \mathrm{COS}$, and $\mathrm{CS}_{2}$, are excreted via expired air. In terms of chemical analysis, metam is photosensitive and decomposes in minutes [10].

Nine of the 45 EDCs are metabolically stable chemicals but were in body fluids at levels below the analytical limit of detection [14-16]. These nine EDCs include: benzyl butyl phthalate (BBP) (CASRN 85-68-7) [14]; 3-benzylidene camphor (3BC) [15]; 1,7,7-trimethyl-3-(phenylmethylene)bicyclo[2.2.1] heptan-2- one (phenylmethylene)bicyclo[2.2.1]heptan-2one (CASRN 15087-24-8) [15]; dicyclohexyl phthalate (DCHP) (CASRN 84-61-7) [14]; dihexyl phthalate (DHP) (84-75-3) [14]; diisobutyl phthalate (DiBP) (CASRN 84-69-50); diisodecyl phthalate (DiDP) (CASRN 26761-40-0) [14]; dioctyl phthalate (DOP)(CASRN 117-81-7) [14]; diundecyl phthalate (DuDP), branched and linear (CASRN 85507-79-5) [14]; and resorcinol (CASRN 108-46-3) [16].

Three of the 45 EDCs were measured at less than 1 nanogram (ng)/milliliter ( $\mathrm{ml}$ ) [17-19]. Five of the 45 EDCs were measured at levels from 1-10 ng/ml [17,20-22]. Two of the 45
EDCs were measured at levels from $10-20 \mathrm{ng} / \mathrm{ml}[15,23]$. Two of the 45 EDCs were detected at levels between 20 and $50 \mathrm{ng} /$ $\mathrm{ml}[19,24]$. One of the 45 EDCs was detected at a level of 50$100 \mathrm{ng} / \mathrm{ml}$ [20]. Three of the 45 EDCs were detected at levels between 100 and $150 \mathrm{ng} / \mathrm{ml}[20,25,26]$. The four EDCs reported at the highest levels were: Dibutyl phthalate (DBP) (CASRN 84-74-2), detected at $0.18-13.47 \mu \mathrm{g} / \mathrm{ml}$ [27]; diethyl phthalate (DEP) (CASRN 84-66-2), detected at $0.64-3.11 \mu \mathrm{g} / \mathrm{ml}$ [27]; bisphenol F (CASRN 620-92-8), detected at $212 \mathrm{ng} / \mathrm{ml}$ [25]; and butylated hydroxytoluene (CASRN 128-37-0), detected at 4.4$273.9 \mathrm{ng} / \mathrm{g}$ [28]. In summary, each of the 45 EDCs is found in human body fluids at very low levels or at concentrations so low as to be below the current analytical detection limit.

\section{Routine exposures to naturally occurring chemi- cals are extremely high}

Testing to determine the endocrine disrupting potential of chemicals is conducted according to standardized protocols. In 2012 and then in 2018, the Organization for Economic Co-operation and Development (OECD) released its "Revised Guidance Document 150 on Standardized Test Guidelines for Evaluation of Chemicals for Endocrine Disruption" [29]. The OECD guidance document focuses on the disruption of estrogen, androgen, thyroid hormones, and steroidogenesis. The United States Environmental Protection Agency (USEPA) has published similar guidance documents detailing in vitro and in vivo tests for endocrine disruption [11,12]. In addition to these assay methods, computer-based models can also be used to estimate the endocrine disruptor potential of chemicals, e.g. the United States Food and Drug Administration (USFDA) Endocrine Disruptor Knowledge Base (EDKB) [13]. One aspect of the EDKB program is predicting the affinity for binding of chemicals to estrogen and androgen nuclear receptor proteins.

The number of naturally occurring chemicals to which humans are routinely exposed is enormous, and the concentrations are significant. First, $99.9 \%$ of the pesticides to which humans are exposed are naturally produced by plants as a de- 
fense mechanism against insect and animal predation [30,31]. It has been estimated that Americans eat about 1.5 grams of natural pesticides per person per day while eating common vegetables including tomatoes, potatoes, and legumes, or drinking coffee [30]. For example, in cabbage alone, 49 chemicals have been identified [30]. The chemical constituents in cabbage represent but a small fraction of chemicals that humans ingest when eating plants. Duke has stated that tens of thousands of secondary plant products have been identified and that hundreds of thousands of such compounds are thought to exist [31].

Second, a very large number of chemicals of diverse structures reported as mutagens, rodent carcinogens, and endocrine disruptors are found in common foods and drinks $[32,33]$. Among these chemicals to which humans are exposed via diet are the polycyclic aromatic hydrocarbons (PAHs), N-nitrosamines, and heterocyclic amines [32,33].

Third, the healthy human gut usually contains between 300 to 1000 different species of bacteria [34,35], with 30 to 40 species accounting for $99 \%$ of the total bacterial count [36]. The mass of bacteria residing in the gut of an average-sized $(70 \mathrm{~kg})$ man is estimated to weigh about $0.2 \mathrm{~kg}$ [37]. Sender, et al. estimate that the number of cells in an average man's body and the number of bacteria in his gut are similar, i.e. 3.0 $\times 10^{13}$ human cells and $3.8 \times 10^{13}$ bacteria [37]. The huge number of bacteria in the human gut produces a large number of different chemicals [38].

Fourth, 25 million metric tons of synthetic persistent organic pollutants (POPs) were produced worldwide from 1945 to 2015 [39]. A number of natural processes produce comparatively large amounts of organic compounds. Common wood-degrading and forest litter-degrading fungi produce $9,900,000$ metric tons yearly of chlorinated anisyl metabolites including tetrachloro-4-methoxyphenol and tetrachloro-1,4-dimethoxybenzene [40,41]. Microorganisms in temperate and boreal forest soils produce $11,600,000$ metric tons yearly of chlorinated organic substances (OCI) [42-45]. Marine macroalgae produce 13.3 tons yearly of the volatile halogenated chemicals $\mathrm{CHBr}_{3}, \mathrm{CHBr}_{2} \mathrm{Cl}$, and $\mathrm{CH}_{2} \mathrm{Br}_{2}[46,47]$. Each year, volcanoes release $3,000,000$ tons of volatile halogenated chemicals including $\mathrm{HCl}$, and $11,000,000$ tons of $\mathrm{HF}$ [48-50]. Volcanoes, forest fires, and burning municipal solid waste (MSW) release 13.1 tons per year of dioxins, polychlorinated dibenzofurans, and polychlorinated dibenzo-p-dioxins [51]. The yearly quantity of organic compounds produced in nature that are either themselves relatively stable, or can react (e.g. $\mathrm{HCl}, \mathrm{HF}$ ) with other naturally occurring compounds and form relatively stable compounds is astronomical at an estimated release into the environment of 1.79 billion metric tons yearly. Assuming that yearly worldwide releases of organic compounds into the environment by natural sources have remained approximately stable during the post-War period, the total tons of organic compounds released into the environment over the 70-year period from 1945-2015 is an astronomical 125 billion metric tons. Therefore, natural releases of organic compounds into the environment exceed synthetic production of POPs over the same time period by 5,000 -fold.
EDCs classified to date fall into a number of different common chemical classes including benzophenones; phthalates; camphor; phenols; bisulphides; acrylates; dithiocarbamates; siloxanes; triazoles; and ethers. It can be anticipated that as more chemicals are tested that additional chemical classes will display endocrine disrupting activity. Many billions of pounds of chemicals are produced each year naturally by plants as pesticides; ingested in foods and beverages; made by gut bacteria; or produced by a variety of natural processes including common wood- and forest litter-degrading fungi; microorganisms in temperate and boreal forest soils; bacteria in marine sponges; marine macro-algae; volcanoes; and forest fires. Many of these naturally produced chemicals fall under the chemical classifications which include currently classified EDCs, and many thousands of naturally produced chemicals are yet to be tested for endocrine activity. Therefore, it can be safely assumed that exposure to naturally produced chemicals possessing endocrine activity greatly exceeds the sub-nanogram, nanogram and microgram levels of exposures to synthetic EDCs.

\section{Exposure to synthetic EDCs is not geographically or temporally associated with obesity rates}

Obesity has risen rapidly both worldwide and in the United States (US) over the last several decades. In 2014, it was estimated that more than 1.9 billion adults were overweight with over 600 million classifiable as obese [52]. Approximately two-thirds of US adults over 20 years of age are currently classified as overweight with about $35 \%$ classified as obese [53]. The obesity rate in the US is predicted to reach $42 \%$ by 2030 in people over 18 years of age [54].

Obesity rates vary greatly by country, with no correlation between potential exposure to EDCs as indicated by degree of industrialization and obesity [55]. Across the US, exposures to EDCs would be expected to be similar. Despite the similarity in EDC exposure, obesity rates vary significantly by state from West Virginia's obesity rate of $38.1 \%$ to Colorado's rate of $22.6 \%$ [56]. Higher rates of obesity were correlated with lower levels of education [57], lower incomes [58], and ethnicity [59]. A number of studies have reported a genetic predisposition toward developing obesity [60]. In addition to genetics, a number of changes in lifestyle are correlated with increased rates of obesity including transitioning from living at home in high school to going away to college [61], decommissioning out of the military [62], and immigrating from a low obesity country to a high obesity country [63]. Obesity rates also do not correlate with the time scale of EDC production and dissemination into the environment as the rates of obesity in the US and worldwide have risen much more rapidly over the last several decades than have environmental exposures to EDCs [64].

\section{Possible explanation of absence of a relationship between obesity and EDCs}

In a recent editorial entitled "Human exposure to synthetic endocrine disrupting chemicals (S-EDCs) is generally negligible as compared to natural compounds with higher or comparable endocrine activity. How to evaluate the risk of 
the S-EDCs?" [65], a possible explanation for the absence of a relationship between obesity and EDCs was addressed.

Sifakis, et al. [66] have "evaluated the available epidemiological studies on the effects of synthetic endocrine disrupting chemicals (S-EDCs) in humans and concluded that due to the complexity of the clinical protocols, the degree of occupational and environmental exposure, the variable endpoints measured, and sample sizes, causal relationships between the reproductive disorders and exposure to specific toxicants (S-EDCS) are not established." It is expected that these or similar confounders are also at play in studies of EDCs as they effect obesity and as a result causal relationship between obesity and exposure to specific toxicants (S-EDCs) are also not well established.

\section{Hormonal and pro-inflammatory effects of adi- pose tissue}

On a population basis, endocrine disrupting chemicals play an insignificant role in the development of obesity. In contrast, adipose tissue itself is composed of a number of different types of secretory cells including adipocytes; precursor cells; endothelial cells; macrophages; foam cells; neutrophils; lymphocytes; fibroblasts; and other cells [67-69]. The range of biological activities, structural diversity, and sheer number of different molecules secreted by adipose tissue is enormous. Molecules secreted by adipose tissue include the following.

- Cytokine and cytokine-like proteins including tumor necrosis factor alpha (TNF $\alpha$ ), interleukin 6 (IL-6), monocyte chemotactic factor 1 (MCP-1), resistin and progranulin

- Proteins of the fibrinolytic system including plasminogen activator inhibitor (PAI-1) and Tissue Factor

- Complement and complement-related proteins including Adipsin, Complement Factor B, acylating simulation protein (ASP) and C1q/TNF-related proteins (CTRPs)

- Enzymes including dipeptidyl peptidase-4 (DPP-4)

- Lipid transport molecules including apolipoprotein E, cholesterol ester transfer protein, and lipoprotein lipase

- Endocannabinoids and other lipids including anandamide, 2-arachidonoylglycerol (2-AG) and free fatty acids; and

- Proteins of the Renin Angiotensin System (RAS) including angiotensinogen [70].

The class of molecules secreted by fat cells, termed adipokines, is sufficiently complex and important that it merits separate discussion. Approximately 500 adipokines have been discovered to date with the following examples demonstrating the extremely wide range of biochemical and physiological reactions reported in the literature: Leptin, discovered in 1994, regulates appetite; adiponectin, discovered in 1995, enhances insulin sensitivity and lessens inflammation; ADAMTS1, discovered in 1997, affects fat stem cell differentiation, blood vessel formation, and ovulation; chemerin, discovered in 1997, increases inflammation and blood pressure; resistin, discovered in 2001, mediates insulin resistance; retinol-binding protein 4 , discovered in 2005, affects insulin resistance; lipocalin-2, discovered in 2007, increases insulin resistance and inflammation; isthmin-1, discovered in 2014, improves fat metabolism in the liver, mediates immune function, and influences embryonic developmental patterning; asprosin, discovered in 2016, modulates glucose release from the liver; Slit2-C, discovered in 2016, stimulates glucose metabolism; and lipocalin-5, discovered in 2018, improves skeletal muscle respiration $[67,68]$.

Adipose tissue is very hormonally active as demonstrated by possessing a large number of different receptors for traditional endocrine hormones [69] including the following: Insulin receptor; glucagon receptor; growth hormone (GH) receptor; thyroid stimulating hormone (TSH) receptor; gastrin/CCK-B receptor; glucagon like peptide-1 receptor; and angiotensin II receptors type 1 and 2 . Adipose tissue possesses enzymes capable of activating, interconverting, and inactivating steroid hormones $[70,71]$. A number of different enzymes that produce steroids are expressed in adipose tissue including cytochrome P450-dependent aromatase; 3-hydroxysteroid dehydrogenase (3HSD); 11HSD1; 17HSD; 7-hydroxylase; 17-hydroxylase; 5-reductase; and UDP-glucuronosyltransferase 2B15 [70,71].

\section{Role of receptors in obesity}

In Smith, et al. [4,5], receptors relevant to obesity, insulin resistance, and the metabolic syndrome were described as "... adipose tissue is hormonally active, possessing a large number of different receptors for classical endocrine hormones [69]. Insulin and glucagon receptors are present as are receptors for growth hormone, thyroidstimulating hormone (TSH), gastrin/CCK-B, glucagon-like peptide-1, and angiotensin II receptors types 1 and 2 . Adipose tissue also possesses enzymes capable of activating, interconverting, and inactivating steroid hormones [70,71].

"The relationships among obesity, the metabolic syndrome, and type 2 diabetes mellitus are complex and have been reviewed by Hardy, et al. [72]. Although abdominal (visceral) adipose tissue increases the risk for developing insulin resistance and type 2 diabetes, increased subcutaneous adipose tissue decreases the risk for these conditions. Hardy, et al. [72] hypothesized that excess fatty acids released by visceral adipose tissue drain into the portal vein, impair insulin signaling, and induce inflammation and cytokine production by macrophages. Ye [73] has reviewed inflammatory mechanisms influencing insulin resistance via inhibition of insulin signaling in adipocytes and hepatocytes. First, insulin receptor substrate 1 and insulin receptor are inhibited by inflammation [74,75]. Second, inflammation impairs PPARc (peroxisome proliferator-activated receptor c) function $[76,75]$. Third, inflammation increases plasma free fatty acids via stimulation of lipolysis and inhibition of triglyceride synthesis [77]. This third mechanism proposed by Ye [73] is consistent with the mechanism proposed by Hardy, et al. [72]."

\section{Conclusions}

While exposure to synthetic EDCs is not a major factor in developing obesity, the converse is true; adipose tissue is an important source of estrogens, testosterone, thyroid stimulating hormone, leptin, and approximately 500 biologically 
active compounds termed adipokines. The hormonal and pro-inflammatory effects of adipose tissue underlie the association between obesity and increased risk of a number of chronic diseases.

In certain regulatory settings, consideration of the potential effects of exposure to EDCs is appropriate $[3,7,8]$. Within the context of public health, efforts to address the extremely serious health consequences of already unacceptably high and still rising obesity rates, an inordinate focus on exposures to nano-molar and micro-molar levels of synthetic EDCs is misplaced. Educational efforts should continue to emphasize awareness of caloric content and portion sizes [78] in addition to increasing physical activity levels [79].

\section{Authors' Contributions}

CJS, TAP, AWH and SCB contributed to manuscript conception, design, and writing in all areas of the manuscript. CJS, TAP, AWH and SCB contributed to conception and design and critical revisions for intellectual content. All authors have approved the paper to be published.

\section{Consent for Publication}

All authors consent to publication in the journal.

\section{Ethical Approval}

No human participants were involved in this paper and no new data were collected; thus, ethical approval was not required.

\section{Declaration of Conflicting Interests}

The authors declared no potential conflicts of interest with respect to the research, authorship, and/or publication of this article.

\section{Funding}

The authors disclose that there is no outside sources of funding for the research, authorship, and/or publication of this article.

\section{References}

1. World Health Organization (2016) Childhood overweight and obesity.

2. Centers for Disease Control and Prevention (2015) The health effects of overweight and obesity.

3. Bergman A, Heindel JJ, Jobling S, et al. (2012) State-of-the-science of endocrine disrupting chemicals. Toxicology Letters 211: S3.

4. Smith CJ, Perfetti TA, Hayes AW, et al. (2020) Obesity as a source of endogenous compounds associated with chronic disease: A review. Toxicological Sciences 175: 149-155.

5. Smith CJ, Perfetti TA, Hayes AW, et al. (2020) Clinical epidemiology studies on potential effects of endocrine disrupting chemicals (EDCs) should exclude subjects with obesity as determined by BMI. Regulatory Toxicology and Pharmacology 115: 104711.

6. Lauretta R, Sansone A, Sansone M, et al. (2019) Endocrine disrupting chemicals: Effects on endocrine glands. Front Endocrinol (Lausanne) 10: 178.
7. The International Panel on Chemical Pollution (2017) United Nations Environment Programme. Overview report I: Worldwide initiatives to identify endocrine disrupting chemicals (EDCs) and potential EDCs.

8. European Chemical Agency (ECHA) (2019) Endocrine disruptor assessment list.

9. National Institute of Environmental Health Sciences (2019) Endocrine disruptors.

10. European Food Safety Authority (2008) Conclusion regarding the peer review of the pesticide risk assessment of the active substance metam. EFSA Scientific Report 203: 1-97.

11. United States Environmental Protection Agency (US EPA) (1998) Endocrine disruptor screening and testing advisory committee (EDSTAC) final report EDSTAC final report. Chapter five.

12. United States Environmental Protection Agency (US EPA) (1998) Endocrine disruptor screening and testing advisory committee (EDSTAC) final report EDSTAC final report, Appendix K.

13. Ding D, Xu L, Fang H, et al. (2010) The EDKB: An established knowledge base for endocrine disrupting chemicals. BMC Bioinformatics 11: S5.

14. Genuis SJ, Beesoon S, Lobo RA, et al. (2012) Human elimination of phthalate compounds: Blood, urine, and sweat (BUS) study. The Scientific World Journal 2012.

15. Janjua NR, Kongshoj B, Andersson AM, et al. (2008) Sunscreens in human plasma and urine after repeated whole-body topical application. J Eur Acad Dermatol Venereol 22: 456-461.

16. European Chemical Agency (ECHA) (2017) Substance evaluation conclusion as required by REACH Article 48 and Evaluation report for Resorcinol, EC No 203-585-2, CAS No 108-46-3. Evaluating Member State(s): Finland.

17. Bae J, Kim S, Kannan K, et al. (2016) Couples' urinary concentrations of benzophenone-type ultraviolet filters and the secondary sex ratio. Sci Total Environ 543: 28-36.

18. Guo J, Wu C, Lu D, et al. (2017) Urinary paraben concentrations and their associations with anthropometric measures of children aged 3 years. Environ Pollut 222: 307-314.

19. The Danish Environmental Protection Agency (DEPA) (2013) Survey of alkylphenols and alkylphenol ethoxylates.

20. Ruszkiewicz JA, Pinkas A, Ferrer B, et al. (2017) Neurotoxic effect of active ingredients in sunscreen products, a contemporary review. Toxicol Rep 4: 245-259.

21. Clark KM (2018) The effect of urinary triclosan on serum thyroxine in US population: 2011-2012 NHANES Data. Wright State University, Dayton, Ohio.

22. Bai XY, Lu SY, Xie L, et al. (2019) A pilot study of metabolites of organophosphorus flame retardants in paired maternal urine and amniotic fluid samples: Potential exposure risks of tributyl phosphate to pregnant women. Environ Sci Process Impacts 21: 124-132.

23. Rochester JR, Bolden AL (2015) Bisphenol S and F: A systematic review and comparison of the hormonal activity of bisphenol $A$ substitutes. Environ Health Perspect 123: 643-650.

24. Ye X, Bishop AM, Reidy JA, et al. (2006) Parabens as urinary biomarkers of exposure in humans. Environ Health Perspect 114: 1843-1846.

25. Lee SW, Lee WJ, Chae HW, et al. (2009) Determination of serum di-(2-ethylhexyl) phthalate and bisphenol a level in children with 
idiopathic central precocious puberty. J Korean Soc Pediatr Endocrinol 14: 154-162.

26. Kim H, Jang $\mathrm{CH}$ (2007) Sensitive determination of eleven phenolic endocrine-disrupting chemicals in human urine using gas chromatography/mass spectrometry-selected ion monitoring. Environ Eng Res 12: 93-100.

27. Jeng HA (2014) Exposure to endocrine disrupting chemicals and male reproductive health. Front Public Health 2: 55.

28. Nordic Council of Ministers (2018) New EU criteria for endocrine disrupters - Consequences for the food chain.

29. Organisation for Economic Co-operation and Development (OECD) (2019) OECD work related to endocrine disrupters.

30. Ames BN, Profet M, Gold LS (1990) Dietary pesticides (99.99\% all natural). Proc Natl Acad Sci U S A 87: 7777-7781.

31. Duke SO (1990) Natural pesticides from plants. In: J Janick, JE Simon, Advances in new crops. (edn), Timber Press, Portland, OR, 511-517.

32. Rodgman A, Perfetti TA (2013) The chemical components of tobacco and tobacco smoke. CRC Press, Taylor \& Francis Group.

33. Smith CJ, Payne V, Doolittle DJ, et al. (1992) Mutagenic activity of a series of synthetic and naturally occurring heterocyclic amines in Salmonella. Mutat Res 279: 61-73.

34. Guarner F, Malagelada J (2003) Gut flora in health and disease. Lancet 361: 512-519.

35. Sears CL (2005) A dynamic partnership: Celebrating our gut flora. Anaerobe 11: 247-251.

36. Beaugerie L, Petit JC (2004) Antibiotic-associated diarrhoea. Best Practice \& Research Clinical Gastroenterology 18: 337-352.

37. Sender R, Fuchs S, Milo R (2016) Revised estimates for the number of human and bacteria cells in the body. PLoS Biol 14: e1002533.

38. Nicholson JK, Holmes E, Kinross J, et al. (2012) Host-gut microbiota metabolic interactions. Science 366: 1262-1267.

39. Carvalho FP (2017) Pesticides, environment, and food safety. Food and Energy Security 6: 48-60.

40. de Jong E, Field JA, Spinnler HE, et al. (1994) Significant biogenesis of chlorinated aromatics by fungi in natural environments. Appl Environ Microbiol 60: 264-270.

41. Woitas R (2014) Naturally occurring persistent organic pollutant. ESSAI 12: 156-158.

42. Clarke N, Fuksová K, Gryndler M, et al. (2009) The formation and fate of chlorinated organic substances in temperate and boreal forest soils. Environ Sci Pollut Res Int 16: 127-143.

43. Agarwal V, Blanton JM, Podell S, et al. (2017) Metagenomic discovery of polybrominated diphenyl ether biosynthesis by marine sponges. Nat Chem Biol 13: 537-543.

44. Stone RP, Lehnert H, Reiswig H (2011) A guide to the deep-water sponges of the Aleutian Island Archipelago. NOAA 12.

45. Vasanthabharathi V, Jayalakshmi S (2017) Diversity and distribution of indole acetic acid producing marine sponge associated bacteria from Gulf of Mannar, southeast coast of India. Global Veterinaria 19: 487-490.

46. World Bank Group (2015) Seaweed aquaculture for food security, income generation and environmental health in tropical developing countries.
47. Suzuki M, Vairappan CS (2005) Halogenated secondary metabolites from the Japanese species of red algae genus Laurencia (Rhodomelaceae, Ceramiales). Current Topics in Phytochemistry 5: 1-38.

48. (2018) Organic halogen compounds. Chemistry Explained.

49. Gribble GW (1992) Naturally occurring organohalogen compounds--a survey. J Nat Prod 55: 1353-1395.

50. Gribble GW (2003) The diversity of naturally produced organohalogens. Chemosphere 52: 289-297.

51. Brzuzy LP, Hites RA (1996) Global mass balance for polychlorinated dibenzo-p-dioxins and dibenzofurans. Environ Sci Technol 30: 1797-1804.

52. Picon-Ruiz M, Morata-Tarifa C, Valle-Goffin JJ, et al. (2017) Obesity and adverse breast cancer risk and outcome: Mechanistic insights and strategies for intervention. CA Cancer J Clin 67: 378397.

53. Ogden CL, Carroll MD, Kit BK, et al. (2014) Prevalence of childhood and adult obesity in the United States, 2011-2012. JAMA 311: 806-814.

54. Finkelstein EA, Khavjou OA, Thompson $\mathrm{H}$, et al. (2012) Obesity and severe obesity forecasts through 2030. Am J Prev Med 42: 563-570.

55. (2016) The world factbook. Country comparison: Obesity - adult prevalence rate. Central Intelligence Agency.

56. World Population Review (2019) Obesity rate by state 2019.

57. Ogden CL, Fakhouri TH, Carroll MD, et al. (2017) Prevalence of obesity among adults, by household income and education United States, 2011-2014. MMWR 66: 1369-1373.

58. Bentley RA, Ormerod P, Ruck DJ (2018) Recent origin and evolution of obesity-income correlation across the United States. Palgrave Communications 4: 146.

59. Office of Minority Health (2018) Obesity and African Americans.

60. Centers for Disease Control and Prevention (2018) Behavior, environment, and genetic factors all have a role in causing people to be overweight and obese.

61. Vadeboncoeur C, Townsend N, Foster C (2015) A meta-analysis of weight gain in first year university students: Is freshman 15 a myth? BMC Obes 2: 22.

62. Littman AJ, Jacobson IG, Boyko EJ, et al. (2013) Weight change following US military service. Int J Obes (Lond) 37: 244-253.

63. Associated Press (2004) Immigrants to the US arrive thin, get fat.

64. Hales CM, Fryar CD, Carroll MD, et al. (2018) Trends in obesity and severe obesity prevalence in US youth and adults by sex and age, 2007-2008 to 2015-2016. JAMA 319: 1723-1725.

65. Autrup H, Barile FA, Berry C, et al. (2020) Human exposure to synthetic endocrine disrupting chemicals (S-EDCs) is generally negligible as compared to natural compounds with higher or comparable endocrine activity. How to evaluate the risk of the S-EDCs? J Toxicol Environ Health A 83: 485-494.

66. Sifakis S, Androutsopoulos VP, Tsatsakis AM, et al. (2017) Human exposure to endocrine disrupting chemicals: Effects on the male and female reproductive systems. Environ Toxicol Pharmacol 51: 56-70.

67. Fasshauer M, Bluher M (2015) Adipokines in health and disease. Trends Pharmacol Sci 36: 461-470. 
68. Madhusoodanan J (2018) Hormones reveal the secret life of fat cells. Understanding the slew of compounds produced by fat might one day lead to therapeutics for obesity-related conditions.

69. Kershaw EE, Flier JS (2004) Adipose tissue as an endocrine organ. J Clin Endocrinol Metab 89: 2548-2556.

70. Belanger C, Luu-The V, Dupont $P$, et al. (2002) Adipose tissue intracrinology: Potential importance of local androgen/estrogen metabolism in the regulation of adiposity. Horm Metab Res 34: 737-745.

71. Meseguer A, Puche C, Cabero A (2002) Sex steroid biosynthesis in white adipose tissue. Horm Metab Res 34: 731-736.

72. Hardy OT, Czech MP, Corvera S (2012) What causes the insulin resistance underlying obesity? Curr Opin Endocrinol Diabetes Obes 19: 81-87.

73. Ye J (2013) Mechanisms of insulin resistance in obesity. Front Med 7: 14-24.

74. White MF (2002) IRS proteins and the common path to diabetes. Am J Physiol Endocrinol Metab 283: E413-E422.

75. Ye J, Gimble JM (2011) Regulation of stem cell differentiation in adipose tissue by chronic inflammation. Clin Exp Pharmacol Physiol 38: 872-878.
76. Ye J (2008) Regulation of PPARgamma function by TNF-alpha. Biochem Biophys Res Commun 374: 405-408.

77. Ye J (2007) Role of insulin in the pathogenesis of free fatty acid induced insulin resistance in skeletal muscle. Endocr Metab Immune Disord Drug Targets 7: 65-74.

78. Centers for Disease Control and Prevention (2019) Learn how the new nutrition facts label can help you improve your health.

79. Harvard School of Public Health (2019) Obesity prevention source - obesity causes, physical activity.

80. Wang L, Wu Y, Zhang W, et al. (2013) Characteristic profiles of urinary p-hydroxybenzoic acid and its esters (Parabens) in children and adults from the United States and China. Environ Sci Technol 47: 2069-2076.

81. Berger KP, Kogut KR, Bradman A, et al. (2019) Personal care product use as a predictor of urinary concentrations of certain phthalates, parabens, and phenols in the HERMOSA study. J Expo Sci Environ Epidemiol 29: 21-32.

82. Astill BD, Mills J, Fassett DW, et al. (1962) Fate of butylated hydroxyanisole in man and dog. J Ag Fd Chem 10: 315-318.

83. Prah J, Ashley D, Blount B, et al. (2004) Dermal, oral, and inhalation pharmacokinetics of methyl tertiary butyl ether (MTBE) in human volunteers. Toxicol Sci 77: 195-205. 